THE IMPLEMENTATION OF GENRE-BASED APPROACH IN TEACHING WRITING TEXT FOR TENTH GRADE AT SMA YAYASAN PENDIDIKAN MULIA

AN ARTICLE

Submitted in Partial Fulfillment of the Requirements for the Degree of Sarjana Pendidikan

BY:

NURVITA SARI MUSDIANI SILALAHI

Registration Number: 2163321037

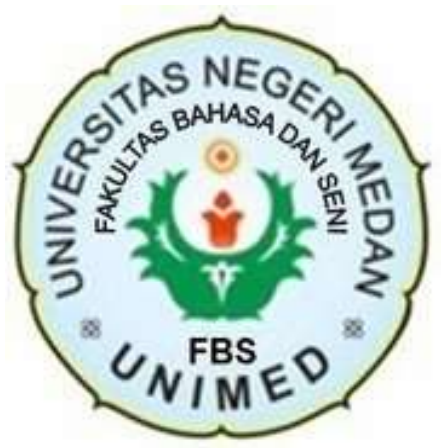

ENGLISH AND LITERATURE DEPARTMENT

FACULTY OF LANGUAGES AND ARTS

STATE UNIVERSITY OF MEDAN

2021 


\section{ARTIKEL \\ THE IMPLEMENTATION OF GENRE-BASED APPROACH IN TEACHING WRITING TEXT FOR TENTH GRADE AT SMA YAYASAN PENDIDIKAN MULIA \\ Disusun dan Diajukan oleh:}

Nurvita Sari Musdiani Silalahi NIM. 2163321037

Telah diverifikasi dan dinyatakan memenuhi syarat untuk diunggah pada jurnal online

Medan, Januari 2021

Menyetujui

Dosen Pembimbing

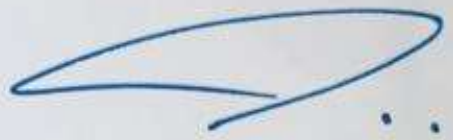

Dr. Masitowarni Siregar, M.Ed. NIP. 196711021993032001

Ka. P. ogram Studi

Pendidikap Bahasa Inggris

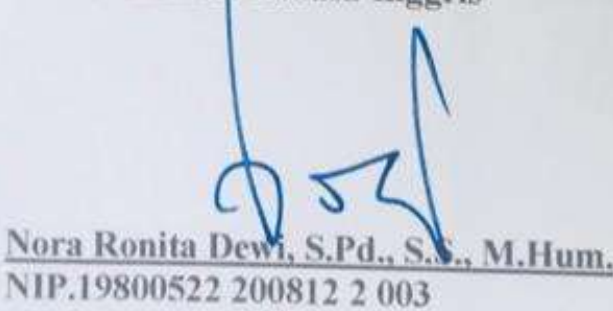




\title{
THE IMPLEMENTATION OF GENRE-BASED APPROACH IN TEACHING WRITING TEXT FOR TENTH GRADE AT SMA YAYASAN PENDIDIKAN MULIA
}

*Nurvita Sari Musdiani Silalahi

**Dr. Masitowarni Siregar, M.Ed.

\begin{abstract}
Nurvita Sari Musdiani Silalahi, 2021. Registration Number: 2163321037. The Implementation of Genre-Based Approach in Teaching Writing Text for Tenth Grade at SMA Yayasan Pendidikan Mulia. A Thesis. English and Literature Department. Faculty Languages and Arts. State University of Medan, 2021.
\end{abstract}

The objectives of this study were to discover the implementation of Genre-Based Approach in teaching writing text for Tenth Grade at SMA Yayasan Pendidikan Mulia and to investigate the reasons why teachers use Genre-Based Approach. This study was conducted by using descriptive qualitative design. The subject of this study was English teacher and students in grade tenth from SMA Pendidikan Mulia. The techniques of collecting data were observation, interview, and documentation. The data were taken from SMA Swasta Mulia Medan, from the research, it was found that in applying Genre-Based Approach in English curriculum, and there are five steps that teacher implemented: building knowledge of field, modeling, joint construction, independent construction and linking related text. From the teacher's interview, the result could be found that the reasons why the teacher of SMA Swasta Mulia Medan using Genre-Based Approach and the problem faced by teacher and also the solution in teaching writing text.

Keywords: Genre-Based Approach, Descriptive Text, Writing Skill.

\footnotetext{
*Graduate Status

** Lecturer Status
} 


\section{INTRODUCTION}

\section{Background of Study}

English is one of many languages in this world. English is an International language and it is spoken by many people around the world. Mastering English is very important in our society in the world, because by learning English, the students may have an opportunity to reach for future successfully. Nowadays, companies need not only ability in their fields, but also people who can have a good English communication.

Learning English is very important for most people, especially in education. This will help learner to develop their English better and easier. In Indonesia, English is used in education started from junior high school until college. It is important to remember that no one particular variety of English is intrinsically better than any other and English language teachers can come from any linguistic background. Because of those reasons, Indonesian applies it as the first foreign language that must be studied by the students.

There are four skills in English learning, they are reading, writing, listening, and speaking. Writing is the most difficult skill among the four for Indonesian students to achieve or master. Therefore, the most effective way or method is urgently needed to solve the problem or difficulty. Consequently, a study needs to be conducted to improve the students' achievement in writing. The present study is aimed at applying a method to improve the students' achievement in writing text. Specifically, the method selected is one which is based on genre or text-based approach.

In teaching learning English, the teacher based on the 2013 Curriculum that known as Genre-Based Approach. In teaching and learning English the teachers' task is to help the students achieve the communicative competence where the teachers are required to have professional competence in order to be able to teach English well. Genre-Based Approach provides stages and strategies to help students have better understanding about text-type. Genre-Based Approach is still relevant with the 2013 Curriculum and one of methodology which can be applied in the classroom, especially in the level of senior high school. Genre-Based Approach is becoming increasingly influential in the field of English language teaching. 
Teaching of English by applying the Genre-Based Approach means that the teaching learning activities focus on learning many kinds of text. Genre means many kinds of text. There are twelve texts that should be taught to the senior high students in Indonesia. Those texts are: recount, report, discussion, explanation, exposition analytical, exposition hortatory, news item, anecdote, narrative, procedure, description and review. A text is a passage whether spoken or written that has unified meaning. A text is influenced by the context of culture and context of situation. It can be short or long, the principle is that the text has meaning, the text is aimed to whom, and what is the way the text is communicated, whether in spoken or written way.

In applying Genre-Based Approach in English curriculum, there are five steps that should be followed: building knowledge of field, modeling, joint construction, independent construction and linking related text. In order to be able to conduct teaching learning activities based genre in the classroom well, teachers have to understand the implementation of the Genre-Based Approach. Understand means that the teachers have knowledge about the Genre-Based Approach and the implementation, they comprehend about the implementation of the Genre-Based Approach and they have opinion to the implementation of the Genre-Based Approach. Based on the facts above, researcher want to discover the implementation of Genre-Based Approach in teaching writing text for tenth grade at SMA Yayasan Pendidikan Mulia and to investigate the problems faced and the solutions.

\section{REVIEW OF LITERATURE}

\section{Writing}

Writing is an important form of communication in daily life. People communicate their ideas, meaning, messages, feeling, emotion, and love not only through speaking but also in writing.

Writing is mental work of inventing ideas, thinking about how to express them, and organizing them into statements and paragraph that will be clearer to a reader (Nunan, 2003: 88). 
The process of inventing ideas happened in the step of pre-writing. Lerdpreedakorn N (2009) also stated that writing was perhaps one of the most important.

Students also can answer questions about the text or imagine that will help them to connect the writer's idea to their own knowledge and experience. By the step, they can express their idea in piece of paper and write what they want. After they finish make their idea they can start organize their idea in their text. They also choose which idea should come first, next, and the last.

Writing helps students to think about ideas carefully and logically. Writing is not as simple as imagined because it is a process of linking words into sentence and paragraph. The organization of ideas is very important. When someone talked about writing, he often thinks about elements like word choices, grammar, and vocabulary.

According to Brown (2000:335) writing is a written product of thinking, drafting, and revising that requires specialized skills on how to generate ideas, how to organize them coherently, how to use discourse markers and rhetorical conventions to put them cohesively into written text, how to revise texts for clear meaning, how to appropriate grammar and how to produce final product.

\section{The Nature of Genre}

Genre is quite easily used to refer to a distinctive category of discourse of any type, spoken or written, with or without literary aspirations. Etymologically, the word 'genre' is derived from the French language meaning 'form' or 'type'. Then, originally, the word 'genre' which is also used in Biology science means 'genus' referring to the classification of flora and fauna (Stokes, 2006; Himawan, 2007). This means that the early concept of genre is to classify the species into a certain class due to its typical similar characteristics (Dirgeyasa, 2015). Most genre use conventions related to communicative purposes, a personal letter starts with a cordial question in a friendly mood because its purpose is to maintain good relationship, and an argument essay emphasizes its thesis since it aims at making an argument. Brown (2001:99) 
stated that, "genre has drawn attention to the ways in which texts are constructed and has identified the characteristics of the different text types." It means that every genre has its own characteristics and social purpose.

\section{The Nature of Genre-Based Approach}

The Genre-Based Approach, also known as a text-based approach, sees communicative competence as involving the mastery of different types of text. Text here is used in a special sense to refer to structured sequences of language that are used in specific ways. Further, Fauziati (2009:209) says that in terms of a classroom implementation, the Genre-Based Approach also resembles the product approach in that a model text is analyzed on the basis of grammatical and text features. Furthermore, Fauziati (2009:223) explain that Genre-Based Approach where teaching and learning is based on the result of genre analysis and which focuses on the understanding and production of selected genres of texts has been around with us since 1970 s and was first popularized as teaching technique.

Genre-Based Approach begins with the whole text as the unit in focus rather than the sentence. The focus on the whole texts implies that there is the higher level of order and patterning in language than just in a sentence-grammar at the level of discourse organization and meta-patterning of grammatical features. A Genre-Based Approach emphasizes that this higher order must be attended to for effective language use.

\section{The Teaching/Learning Cycles}

Feez and Joyce quoted by Madya (2013:90) explain five cycles in Genre-Based Approach. The cycle of teaching and learning activities in the Genre-Based Approach consist of a number of stages which the teacher and students go through so that students gradually gain independent control of a particular text-type. Each of the five stages of the teaching/learning cycle is designed to achieve a different purpose within the cycle of the teaching and learning. Each stage, therefore, is associated with different types of activities. The Five stages are building the context, modeling and deconstructing the text, joint construction of text, independent construction of text, linking to related texts. 
This research conducted by using descriptive qualitative research by Heigham and Croker (2009:9). This study was conducted at SMA Swasta Mulia Medan which is located in Jl. Kenanga Sari No.33 Medan. The subject of this study was the students' achievement and the teacher's teaching using Genre-Based Approach. The instruments of collecting data were interview sheets, recorder and field note. The technique for collecting data were observation, interview and field note.

\section{The Techniques of Data Analysis}

Data reduction means summarizing, choosing and focusing the important thing of data. It is intended to find the patterns of the finding based on the social phenomena that happen in the field. Here the researcher reduced the data from the entire data from the observation. It can be from the documentation and interview from the teacher and students. The reduction is to get the data based on the problem statement. The data was summarized, sorted, and organized. Data display is organizing and describing the data from reduction. In this step, the researcher described the answer of problem statement. This study described all of data from observation, interview, and recording. By interviewed and observationed, the implementation of Genre-Based Approach in teaching writing skill, what factors do support the implementation of Genre-Based Approach in teaching writing skill, and also the problem faced by the teacher in teaching writing skill using Genre-Based Approach has known. The conclusion of the study was a research finding. Drawing conclusion or verification is done if the data collected and analyze are supported by valid, consistent and enough the data. The researcher drawed the conclusion on this last study. The conclusion was the result of the analysis based on the problem statements. It is gotten from the observation.

\section{FINDINGS}

1. The teaching learning process involves into five stages, they are: 1) Building the context, 2) Modeling and deconstructing the text, 3) Joint construction of the text, 4) Independent construction of the text, and 5) Linking related text. In the first stage, the teaching writing skill using Genre-Based Approach is better because before the teacher explains about the material 
of descriptive text, the teacher asks the students about the meaning and giving the student's opportunity to explore their knowledge. In the second stage, it is appropriate with these stages because, in this modeling step the teacher ask the students to read the material that given. The teacher also ask the students to come in front and identify the part of Descriptive text by underlined the generic structure. Sometimes the teacher gives example about how to identify the part of Descriptive text. In the third stage, The process of came in front of the class to present their task without chosen by the teacher, but one of a group came forward and began read their script. In the researcher's opinion, this stage is appropriate with the theory of Joint Construction of Text because in this activity the teacher did questioning, discussing and make small group to discuss the material. The fourth stage, the teacher asks the students expected to work independently with the text. The teacher gave some of reviewers about the materials that related with the genre descriptive text, the students can explain and answer one by one. It is began from the definition of descriptive text, social function, and generic structure and the last is language features of descriptive text. In the fifth stage, the students must be creative, and remember about the teacher's explanation. The teacher gives assignments for the students to read another descriptive text. The teacher asks the students to write about beautiful destination related to descriptive text, after that the teacher will call the students one by one to find the generic structure and language feature of the text in front of the class.

2. The problems faced by the teacher in teaching writing skill using Genre-Based Approach at the tenth grade students of SMA Pendidikan Mulia. There are three problems. The first is the teacher feels difficulty in managing the class especially from the condition and time the teacher feels that the students needing more effort in mastering the material to understand and get the point of the materials. The second problem is when the teacher asked the students to join with their group, then asked them to do their task with their group, the teacher could not monitor all group at once this is because the teacher lack pupil interest. The third problem is the students have some difficulties to translate of the text type especially in the descriptive text. 
3. The solutions of the problems faced by the teacher in teaching writing skill using Genre-Based Approach at the tenth Grade SMA Pendidikan Mulia. The first solution that given by teacher is the teacher before began teach materials the teacher gave advice and motivation, so the students can achieve the material. Besides the teacher also implemented jigsaw method to overcome this problem, because jigsaw method can overcome related to lack of the students activity and asked them to be active during teaching process. The second solution is the teacher sharing interesting experiences, by sharing interesting experiences, it can built up students interest, so that the students who feel lack of pupil interest will be ready to follow the teaching process. The third solution is the teacher asked the students to bring the dictionary to find the difficult word to improve their ability. Because without dictionary the students did not search the meaning of words and unfortunately a writer cannot understand a text without knowing what most of the word mean when they learn English or when they do exercise. Besides, the teacher also asks the students to write down the meaning in the book. The students can consult about the meaning that they find in the dictionary, the teacher believe the solution can solve this problem.

\section{DISCUSSION}

In line with the teaching learning cycle of the theory from Feez and Joyce quoted by Madya (2013:90) explain five cycles in Genre-Based Approach. The cycle of teaching and learning activities in the Genre-Based Approach consist of a number of stages which the teacher and students go through so that students gradually gain independent control of a particular text-type. Each of the five stages of the teaching/learning cycle is designed to achieve a different purpose within the cycle of the teaching and learning.

Assessing writing is not simple for teacher. Brown (2004:218) stated that assessment of writing is not simple task. When you assess students' writing you need to be clear about your objective or criteria. The process of assessing students' writing ability is generally taken from the test. Test is the simple term to know the students ability in writing. The factors in teaching writing which are most often responsible for people to comprehend writing materials are: 1). Classroom management, 2). Knowledge, 3). Vocabulary difficulties, and 4). Lack of pupil interest. 
Each stage is associated with different types of activities. Usually, when a text type and its context are being introduced for the first time, the teacher and the students work through all these stages. However, it is possible to enter the cycle at any point. For example, students are already familiar with the context, the cycle could begin with activities from the modeling stage. It is also possible at any time to return to activities from earlier stages of the cycle if students need revision or further practice in order to progress. Feez and Joyce quoted by Madya (2013:92) stated that the teaching learning cycle includes five stages, they are: 1). Building the context, 2). Modeling and deconstructing the text, 3). Joint construction of the text, 4). Independent construction of the text, and 5). Linking related text.

\section{Conclusion}

Referring to the dissusion of the research in the previous chapter, it can be concluded that there were five stages in teaching writing using Genre-Based Approach, they are: Building the context; Modeling and deconstructing the text; Joint construction of the text , Independent construction of the text; Linking related text. The teacher applied the steps in Genre-Based Approach properly, the teacher followed all rules of teaching learning cycle of Genre-Based Approach. All of those stages the teacher did implement the stage in the teaching learning process of writing skill and could make balancing between the problems faced by the teacher in teaching writing skill using Genre-Based Approach. Because of in using those stages, the teacher paid attention or checked the appropriateness of those stages with the material and also the situation of the class. There were some problems faced by the teacher in teaching writing skill using Genre-Based Approach such as: the teacher felt the students needed an extra time to mastering the materials. Because not all students had same capability in receiving the materials, the teacher also needed more time managing the class to explain the materials until her students could understand toward the materials. The teacher lack pupil interest, because when the teacher monitored one group, the other groups made noisy and did not pay attention to the teacher explanation. The teacher also has problem when the students less vocabulary, this is because not all the students had same capability in receiving the materials, there is any students understand but also any students not understand about vocabulary. 
The solutions of the teacher problems in teaching writing skill using Genre-Based Approach were: the teacher needed managing the class to mastering the materials to solve this problem the teacher before began teach materials the teacher gave advice and motivation, so the students can achieve the material. Teacher must explain step by step until the students understand about the material. The teacher lack pupil interest, to solve this problem, the teacher sharing interesting experiences, by sharing interesting experiences, it can built up students interest, so that the students who feel lack of pupil interest will be ready to follow the teaching process. The students have less vocabulary, to solve this problem, the teachers instructed them to bring dictionary when they learn English or when they do exercise.

\section{REFERENCES}

Bernstein, B. (1990). The Structuring of Pedagogic Discourse. Vol IV, Class, Codes and Control. London: Routledge Kegan Paul

Brown, H. (2000). Principles of Language Teaching and Learning (4th Ed.).New York: Pearson Education.

Brown, H. (2001). Teaching by Principles: An Interactive Approach to Language Pedagogy (2nd Ed.). New York: Pearson Education

Brown, H. (2003). Language Assessment: Principles and Classroom Practices. San Francisco, California: Longman.

Brown, H. (2004). Language Assessment: Principles and Classroom Practices. USA: Pearson Education, Inc.

Creswell, J. (2014). Research Design Qualitative, Quantitative and Mixed Methods Approaches. United Kingdom: SAGE Publications Ltd.

Dirgeyasa, I.W. (2015). What and How to Assess a Genre-Based Writing. Proceeding of 4th International Conference on Language Education. 2015. State University of Makasar South Sulewesi Indonesia.

Destri. (2015). The Implementation of Genre Based Approach in Teaching Reading: A Case Study at SMPN 17 in Pekan Baru. Padang: Journal of English Language Teaching (ELT).

Donald, S.G., and Pauline, E.K. (2001). Study Skills for Language Students: A Practical Guide. New York: Oxford University Press.

Fauziati, Endang. (2002). Teaching of English as a Foreign Language (TEFL). Surakarta: Muhammadiyah University Press.

Fauziati, Endang. (2009). Introduction to Methods and Approaches in Second or Foreign Language Teaching. Surakarta: Era Pustaka Utama.

Feez, S., and Joyce, H. (1998). Text Based Syllabus Design. Sydney: Macquarie University. 
Hammond, J. A., Burn, H., Joice, D., Brosnan, and Gerot, L. (1992). English for Social Purposes: A Handbook for Teaching of Adult Literacy. Sydney: National Centre for English Language Teaching and Research, Macquaries University.

Harmer, J. (2004). How to Teach Writing. Essex: Pearson Education Ltd.

Harmer, J. (2007). The Practice of English Language Teaching (4th Ed.). Essex: Pearson Education Ltd.

Heigham, J., and Robert, A.C. (2009). Qualitative Research in Applied Linguistics A Practical Introduction. New York: Palgrave Macmillan.

Hervinda. (2017). The Implementation of Genre Based Approach in Teaching Reading Skill at Tenth Grade Students of MAN Karanganyar in the Academic Year 2016/2017. Surakarta: IAIN Surakarta.

Hyland, K. (2004). Genre and Second Language Writing. Ann Arbor, MI: University of Michigan Press.

Lailatul, Budi, and Zakiyah. (2017). The Implementation of Genre Based Approach in Teaching Writing at SMPN 7 Jember. Jember: F-KIP e-Proceeding

Lerdpreedakorn, N. (2009). Genre-Based Approach to Teaching Academic Writing. In A. M. Stoke (Ed.), JALT 2008 Conference Proceedings: Tokyo: JALT.

Maslichah, S. (2017). Enhancing Students' Ability in Writing Descriptive Text through Graphic Organizer. Semarang: Journal for Language and Foreign Language Learning.

Moleong, L. J. (2004). Metodologi Penelitian Kualitatif. Bandung: Remaja Rosdakary

Mustika. (2016). The Implementation of Genre Based Approach in Teaching Writing Skill of the Seventh Grade Students of SMP Institut Indonesia. Yogyakarta: Universitas Negeri Yogyakarta.

Nunan. (2003). Practical English Language Teaching. Cambridge: Cambridge University Press.

Richards, J.C. (2006). Communicative Language Teaching Today. New York: Cambridge University Press.

Rusmawan. P.N. (2017). Genre Based Approach to Teach Writing Descriptive Text. Sidoarjo: Journal of English Educators Society.

Sahu, P.K. (2013). Research Methodology: A Guide for Researchers in Agricultural Science, Social Science and Other Related Fields. India: Springer New Delhi Publisher.

Stoke, J. (2006). How to do Media and Cultural Studies diterjemahkan oleh Santri Indah Astuti (Panduan untuk Melaksanakan Penelitian dalam Kajian Media dan Budaya, Yogyakarta: PT. Benteng Pustaka.

Swales, J. M. (1990). Genre Analysis English in Academic and Research Settings. Cambridge: Cambridge University Press.

Van, E. J.A., and Alexander, L.G. (1980). Threshold Level English. Oxford: Pergamon. 